\title{
Penerapan CRM pada Aplikasi Kantor Pelayanan Penyuluhan dan Konsultasi Perpajakan Kota Gunungsitoli (KP2KP)
}

\author{
Hemat Hartama Hia ${ }^{1}$, Naikson Fandier Saragih ${ }^{2}$, Fati Gratianus Nafiri Larosa ${ }^{3}$ \\ * Corresponding author: fatignlarosa@gmail.com \\ 1,2,3 Fakultas Ilmu Komputer Universitas Methodist Indonesia \\ J1. Hang Tuah No 8 Medan
}

Abstract--Extension Service and Tax Consultation Office or Kantor Pelayanan Penyuluhan dan Konsultasi Perpajakan (KP2KP) of Gunungsitoli city needs a continuous effors in improving service for taxpayer. Application of CRM (Customer Relationship Management) by utilizing information technology is one of choices. The research begins with the analysis of non-functional systems that include hardware and software used, as well as analysis of the users involved, NPWP Registration Procedure, Income Tax Payment Procedure. System design in the form of Context Diagram and DFD, and database design in the form of ERD. The step is implementation the program using PHP, implementation the database using MySQL, and the use of SMS Gateway through online SMS service Zenziva and email. After tested with white box method, this system can improve the loyalty aspect and the opening of easy communication channel with high response rate by preparing notification facility of confirmation of NPWP registration, consultation feature for taxpayer to convey suggestions, confirmation of payment, and warning of payment schedule either via SMS and email. This system also can improve taxpayer (customer) satisfaction, increase corporate/government earnings (Tax Targe), increase the competitive advantage compared with other regions. This system can also generate Consultation Reports and reports via SMS and email notifications.

Keywords:Application, CRM, Penyuluhan, Perpajakan, KP2KP

Abstrak--Kantor Pelayanan Penyuluhan dan Konsultasi Perpajakan (KP2KP) Kota Gunungsitoli menginginkan suatu usaha berkelanjutan dalam perbaikan pelayanan terhadap wajib pajak. Aplikasi CRM (Customer Relationship Management) dengan pemanfaatan teknologi informasi adalah salah satu dari berbagai pilihan. Penelitian ini dimulai dengan analisis sistem non-fungsional termasuk perangkat keras dan perangkat lunak yang digunakan, serta analisis pengguna yang terlibat, Prosedur Pendaftaran NPWP, Prosedur Pembayaran Pajak Penghasilan. Perancangan Sistem dalam bentuk Context Diagram dan DFD, perancangan database dalam bentuk ERD. Langkah selanjutnya adalah implementasi program menggunakan PHP, implementasi database menggunakan MySQL, dan penggunaan SMS Gateway melalui layanan SMS online Zenziva dan layanan email. Setelah melakukan pengujian dengan metoda white box, sistem ini dapat meningkatkan aspek loyalitas dan terbukanya saluran komunikasi yang mudah dengan tingkat respon yang tinggi dengan menyiapkan fasilitas notifikasi konfirmasi pendaftaran NPWP, fitur 
konsultasi konsultasi untuk wajib pajak untuk menyampaikan saran, konfirmasi pembayaran, dan peringatan akan jadwal pembayaran baik melalui SMS maupun email. Sistem ini juga dapat memperbaiki kepuasan wajib pajak (customer), meningkatkan pendapatan perusahaan/pemerintah (Target Pajak), meningkatkan keunggulan kompetitif dibanding dengan wilayah lainnya. Sistem ini juga dapat menghasilkan Laporan Konsultasi dan Laporan melalui notifikasi SMS dan notifikasi email.

Kata Kunci: Aplikasi, CRM, Penyuluhan, Perpajakan, KP2KP.

\section{PENDAHULUAN}

Pajak merupakan salah satu penopang pendapatan nasional. Pajak memiliki peran yang sangat vital dalam sebuah negara, tanpa pajak kehidupan negara tidak akan bisa berjalan dengan baik. Dapat dikatakan pajak merupakan ujung tombak pembangunan sebuah negara. Pembayaran pajak merupakan perwujudan dari kewajiban kenegaraan dan peran serta Wajib Pajak untuk secara langsung dan bersama-sama melaksanakan kewajiban perpajakan untuk pembiayaan negara dan pembangunan nasional. Dengan demikian pajak merupakan sebuah alat untuk meningkatkan kesejahteraan dan kemakmuran seluruh warga Negara.

$\begin{array}{cccr}\text { Kantor } & \text { Pelayanan } & \text { Penyuluhan } & \text { Dan } \\ \text { Konsultasi } & \text { Perpajakan } & \text { (KP2KP) } & \text { Kota }\end{array}$
Gunungsitoli terus berusaha menggenjot dan menaikkan target penerimaan Pajak Kota Gunungsitoli dari tahun ke tahun. Hal ini dimaksudkan agar program-program Pemerintah dapat terealisasi. Namun masalah yang dihadapi adalah pengetahuan masyarakat akan pajak masih sempit sehingga mereka masih enggan untuk mendaftarkan dirinya sebagai Wajib Pajak dan membayar pajak sesuai dengan ketentuan yang berlaku. Padahal sistem perpajakan kita sudah menganut self assessment dimana wajib pajak diberikan kewenangan untuk menghitung sendiri, melaporkan sendiri dan membayar sendiri pajak yang terhutang yang seharusnya dibayar. Oleh karena itu pemerintah membuat arah kebijakan umum dengan cara peningkatan pelayanan dan kepatuhan Wajib Pajak dengan didukung perbaikan regulasi, administrasi, serta akuntabilitas.

\section{TINJAUAN PUSTAKA}

CRM (Customer Relationship Management)

CRM adalah sebuah strategi bisnis yang bersifat proaktif bertujuan untuk memupuk kesetiaan konsumen dan membuat mereka berjanji untuk menggunakan produk dan jasa perusahaan. Bila Kesetiaan terhadap suatu produk sudah terbentuk, akan timbul perilaku repeat buyer (pembelian berulang), dimana konsumen akan membeli produk perusahaan yang sama dalam jangka waktu panjang. Dengan situasi ini, sudah tentu perusahan dapat mempertahankan dan meningkatkan volume penjualannya secara terus menerus [3]. Media untuk mewujudkan konsep CRM tersebut menggunakan Internet [8], dengan membangun suatu Website yang baru yang dilengkapi dengan database [4].

Customer Relationship Management adalah strategi atau filosofi yang memberikan visi bagi perusahaan untuk berurusan dengan pelanggan. Strategi manajemen hubungan pelanggan adalah memaksimalkan nilai hubungan. Dibutuhkan strategi dan proses holistik untuk keberhasilannya [10].

Kontak kepada customer pada banyak saluran akan dapat memaksimalkan pendapatan dan juga pelayanan. Cara kontak kepada customer dapat berbeda caranya pada setiap segment pembayar pajak [11].

Berikut ini saluran/teknologi yang dapat digunakan pada proses transaksi, interaksi, dan proses penyampaian informasi. 
TRANSACTIONS

\begin{tabular}{c}
\hline Web \\
\hline Phone \\
\hline Paper \\
\hline Face to Face \\
\hline email not an option \\
\hline
\end{tabular}

INTERACTIONS

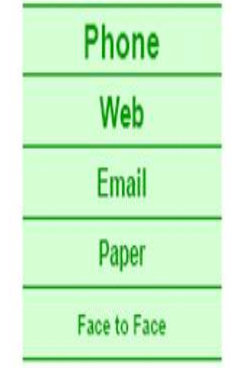

INFORMATION

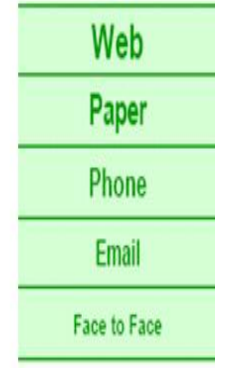

Gambar 1 Pilihan Saluran pada Proses

Transaksi, Interaksi dan Informasi

Sumber :

https://www.oecd.org/tax/administration/38528306.pdf

Sistem CRM yang efisien setidaknya harus dapat memenuhi beberapa hal berikut [11]:

a. Mengidentifikasi faktor-faktor penting untuk pelanggan

b. Mempromosikan filosofi yang berorientasi pada pelanggan

c. Mengadopsi langkah-langkah berbasis pelanggan

d. Mengembangkan setiap proses dengan unsur melayani pelanggan

e. Memberikan reward (dukungan) bagi pelanggan dengan penilaian baik

f. Menangani keluhan pelanggan

\section{Pajak}

Pajak adalah kontribusi wajib kepada negara yang terutang oleh orang pribadi atau badan yang bersifat memaksa berdasarkan Undang-Undang, dengan tidak mendapatkan imbalan secara langsung dan digunakan untuk keperluan negara bagi sebesar-besarnya kemakmuran rakyat [9].

\section{Penyuluhan dan Konsultasi Perpajakan}

Penyuluhan dan Konsultasi Perpajakan dilakukan untuk mengingatkan Wajib Pajak agar tidak melalaikan kewajibannya. Penyuluhan dan Konsultasi Perpajakan merupakan pengawasan kapatuhan perpajakan, memberikan bimbingan/himbauan dan konsultasi teknik perpajakan, penyusunan profil Wajib Pajak, analisis kinerja Wajib Pajak dalam rangka intensifikasi dan melakukan evaluasi hasil banding berdasarkan ketentuan yang berlaku [5].

\section{METODOLOGI PENELITIAN}

Pada tahap ini disusun Context Diagram, Data Flow Diagram [7] dan ERD (Entity
Relationship Diagram) [1]. Hasil perancangan dibuat menjadi Website yang baru menggunakan PHP [6] dan MySQL [2].

\section{Analisis Sistem Yang Sedang Berjalan}

a. Prosedur Pendaftaran NPWP

Prosedur pendaftaran NPWP yang sedang berjalan di KP2KP Gunungsitoli dapat dijelaskan sebagai berikut yakni: (a) Pemohon mengisi kelengkapan data yang dimana kelengkapan data ini akan diperiksa oleh seksi pelayanan; (b) Seksi Pelayanan memeriksa kelengkapan data apabila ada data yang belum lengkap maka berkas yang belum lengkap tersebut akan kembali ke pemohon dan apabila lengkap seksi pelayanan akan mencatat data pemohon yang memiliki berkas yang sudah lengkap; (c) Apabila data berkas pemohon yang sudah lengkap tersebut sudah dicatat, maka seksi pelayanan akan membuat jadwal penerbitan yang dimana jadwal penerbitan ini akan dimasukkan ke dalam berkas dan jadwal penerbitan akan diolah oleh seksi pemeriksaan; (d) Seksi pemeriksaan akan memberikan data penerbitan NPWP dan berkas pemohon apakah sudah sesuai dengan syarat - syarat berkas yang sudah dilampirkan; (e) Apabila pemeriksaan sudah valid maka penerbitan NPWP akan dikembalikan kembali ke seksi pelayanan dan langsung diinformasikan kepada pemohon

b. Prosedur Pembayaran Pajak Penghasilan

Wajib Pajak menyerahkan pembayaran hutang pajak penghasilan kepada bagian administrasi. Bagian administrasi mencatat hutang pajak penghasilan dan bangunan, membuat laporan pembayaran hutang pajak penghasilan dan membuat laporan penerimaan hutang pajak penghasilan, setelah itu administrasi juga harus membuat laporan pertinggal di administrasi yang sudah melakukan pembayaran hutang pajak penghasilan, membuat laporan sudah membayar hutang pajak penghasilan ke wajib pajak dan membuat laporan pembayaran pajak penghasilan dan bangunan dan laporan penerimaan pajak penghasilan dan bangunan ke pimpinan pada setiap akhir bulan.

\section{Context Diagram}

Perancangan Context Diagram yang akan dibuat pada pengolahan data untuk pendafataran 
NPWP dan perhitungan Pajak Penghasilan dapat dilihat pada Gambar 2, yang terdiri dari tiga entitas yakni Admin, Pimpinan dan Wajib Pajak.

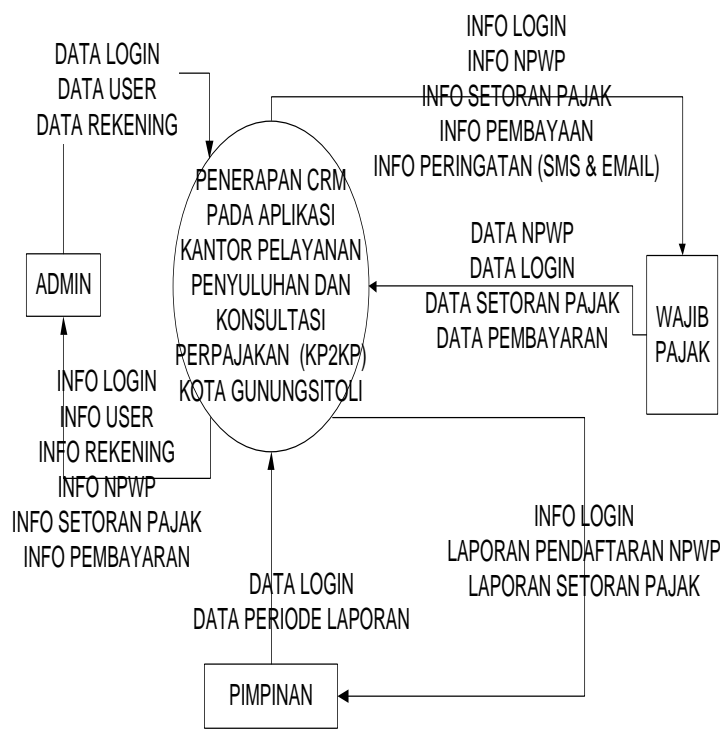

Gambar 2 Context Diagram yang Diusulkan

\section{Data Flow Diagram (DFD) Level 0}

DFD Level 0 merupakan penjabaran dari proses Diagram Konteks. Berikut ini adalah gambar DFD level 0 yang telah dibangun seperti yang terlihat pada Gambar 3 berikut:

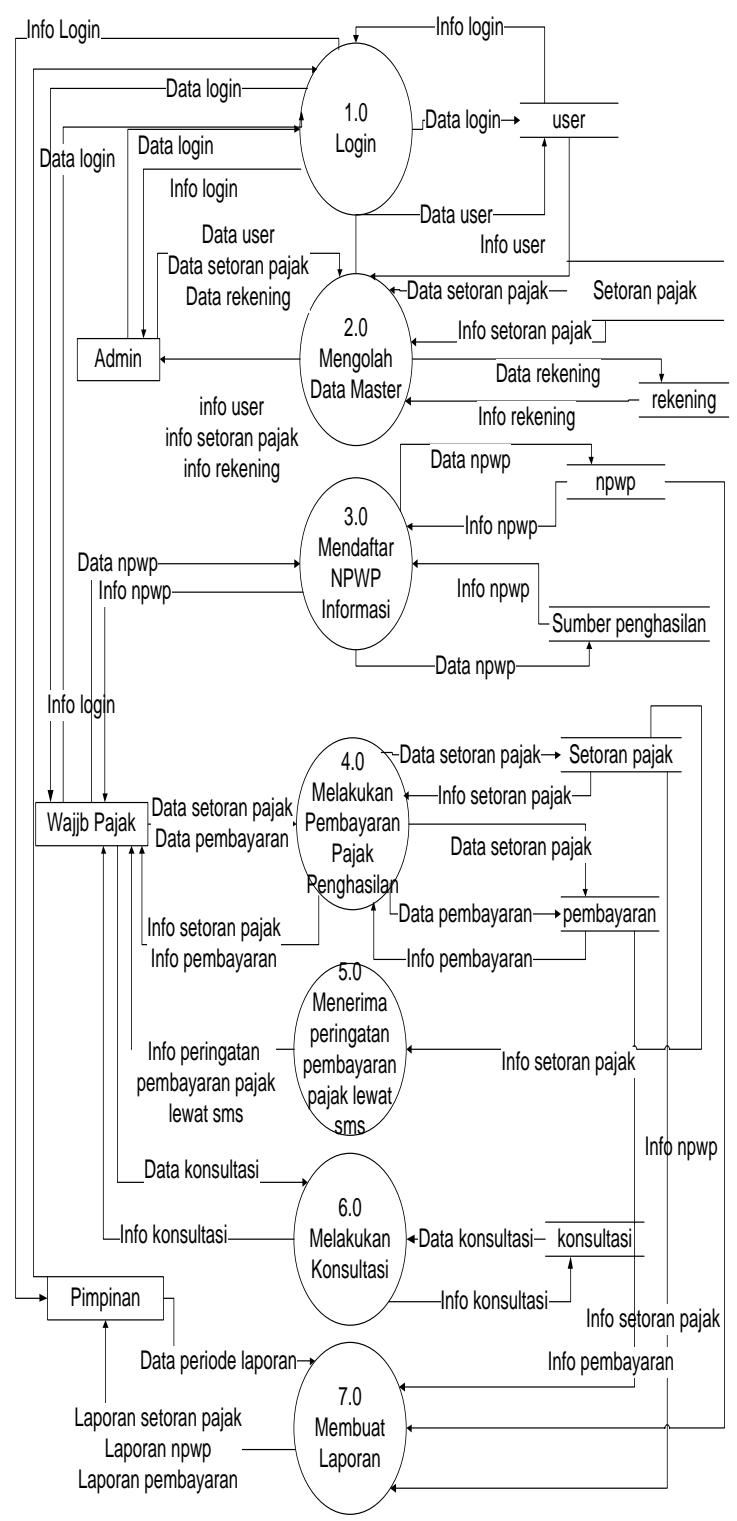

Gambar 3 Data Flow Diagram (DFD) Level 0

\section{IMPLEMENTASI DAN PENGUJIAN}

Implementasi Sistem adalah langkah-langkah atau prosedur yang dilakukan dalam menyelesaikan desain sistem yang telah disetujui, menguji, dan memulai sistem baru yang telah disempurnakan.

\section{Komponen Utama dalam Implementasi Sistem}

Agar sistem Tampilan yang telah dikerjakan dapat berjalan baik atau tidak, maka perlu dilakukan pengujian terhadap sistem yang telah dikerjakan. Oleh karena itu, dibutuhkan beberapa komponen yang mencakup perangkat keras (hardware), perangkat lunak (software), dan pengguna (brainware).

a. Perangkat Keras (Hardware) 
Hardware merupakan komponen yang terlihat secara fisik yang saling bekerja sama dalam pengolahan data. Perangkat keras yang digunakan meliputi: (a) Monitor; (b) CPU (Central Processing Unit); (c) Hardisk sebagai media penyimpanan; (d) Memori minimal 1GB; (e) Keyboard dan Mouse.

b. Perangkat Lunak (Software)

Software adalah instruksi atau programprogram komputer yang dapat digunakan oleh komputer dengan memberikan fungsi serta penampilan yang diinginkan. Dalam hal ini perangkat lunak yang digunakan adalah: (a) OS MicrosoftWindows 7; (b) Adobe Dreamwever CS5 sebagai tools editor untuk mendesain website; (c) XAMPP 1.7.1 dimana terdapat Apache sebagai web server, PHP sebagai bahasa pemrograman yang digunakan, dan MySQL sebagai software untuk server database; (d) Mozilla Firefox 3.5+ untuk menjalankan program yang telah dirancang; (e) Zenziva sebagai layanan Online SMS

c. Pengguna (Brainware)

Brainware merupakan faktor manusia yang menangani fasilitas komputer yang ada. Faktor manusia yang dimaksud adalah orangorang yang memiliki bagian untuk menangani sistem dan merupkan unsur manusia yang meliputi: (a) System Analyst, yaitu orang menganalisa dan merancang prototipe/tampilan sistem; (b) Programmer, yaitu orang yang membangun program; (c) Operator (Administrator), yaitu orang yang mengoperasikan sistem seperti memasukkan data untuk diolah oleh komputer dalam menghasilkan informasi dan lain sebagainya; (d) Public, yaitu orang yang memakai sistem yang telah dirancang untuk informasi yang dibutuhkan.

\section{Tampilan Program}

Pada bagian ini ditunjukkan tampilan program dari hasil rancangan program website yakni Login Admin, Input Data User, Input Data Rekening, Pengisian Data Diri WP, Pengisian Data Tempat Tinggal WP, Sumber Penghasilan WP, Pengolahan Data User, Output Data Rekening, Output Data Peserta WP, Output Pembayaran Pajak,Data Perhitungan Setoran Pajak, Pembayaran Pajak, Input Data Konsultasi, SMS Notifikasi Pendaftaran WP, SMS Reminder Pembayaran Pajak, SMS Notifikasi Pembayaran
Pajak, Email Notifikasi Pendaftaran WP,Email Notifikasi Pembayaran Pajak, Laporan Pendaftaran WP dan Laporan Pembayaran Pajak.

\section{Tampilan Login Admin}

Tampilan login berfungsi bagi admin menginput data username dan password sebelum masuk ke halaman akun. Tampilan Login Admin dapat dilihat pada Gambar 4

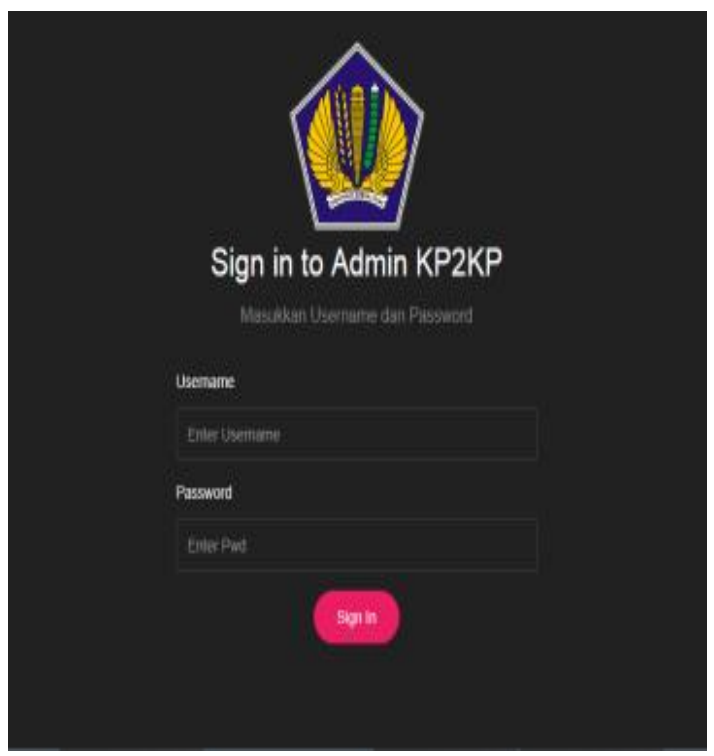

Gambar 4 Login Admin

\section{Tampilan Input Data User}

Tampilan input data user berfungsi bagi admin menginput data user yang baru. Data yang diinput adalah username, password, konfirmasi password, dan level. Tampilan Input Data User dapat dilihat pada Gambar 5.

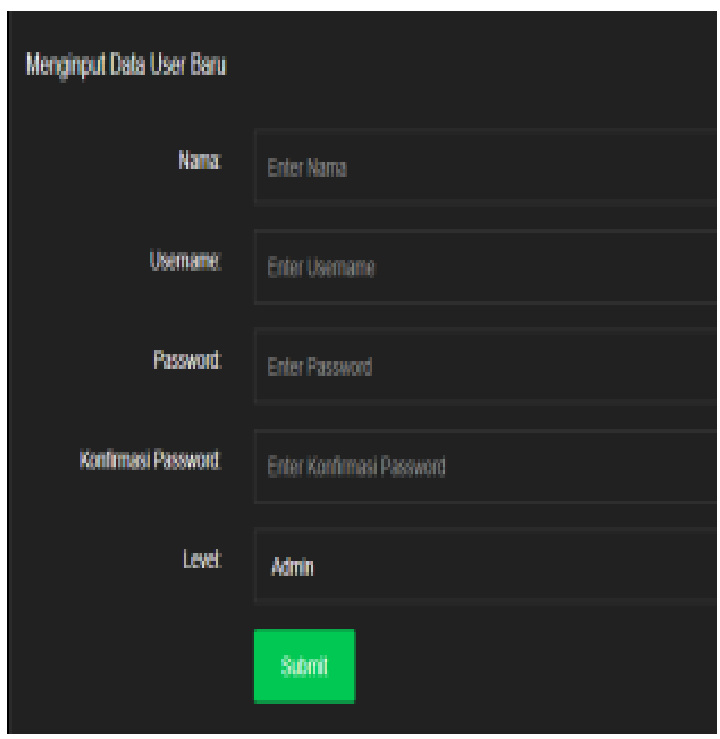

Gambar 5 Input Data User 


\section{Tampilan Input Data Rekening}

Tampilan input data Rekening berfungsi bagi admin menginput data Rekening yang baru. Data yang diinput adalah nama Rekening. Tampilan Input Data Rekening dapat dilihat pada Gambar 6.

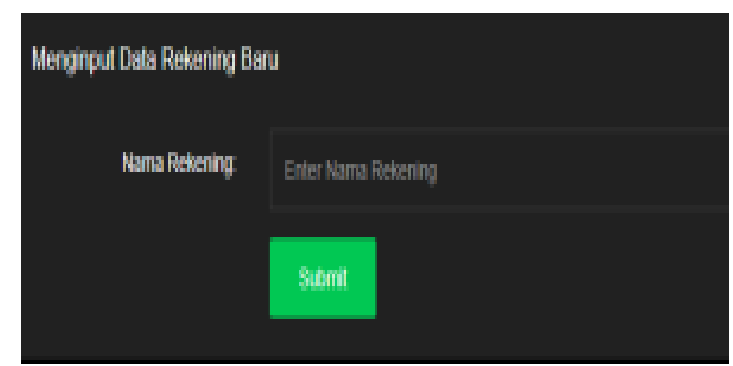

Gambar 6 Input Data Rekening

\section{Tampilan Pengisian Data Diri WP}

Tampilan Pengisian Data DiriWP berfungsi bagi Wajib Pajak untuk mengisi data diri saat proses pendaftaran NPWP berlangsung. Data yang diinput adalah nama wajib pajak, gelar, tempat lahir, tanggal lahir, status perkawinan, kebangsaan, nomor KTP, nomor passport, nomor HP, dan password. Tampilan Input Data Diri WP dapat dilihat pada Gambar 7.

\section{Step 1: Pengisian Data Din}

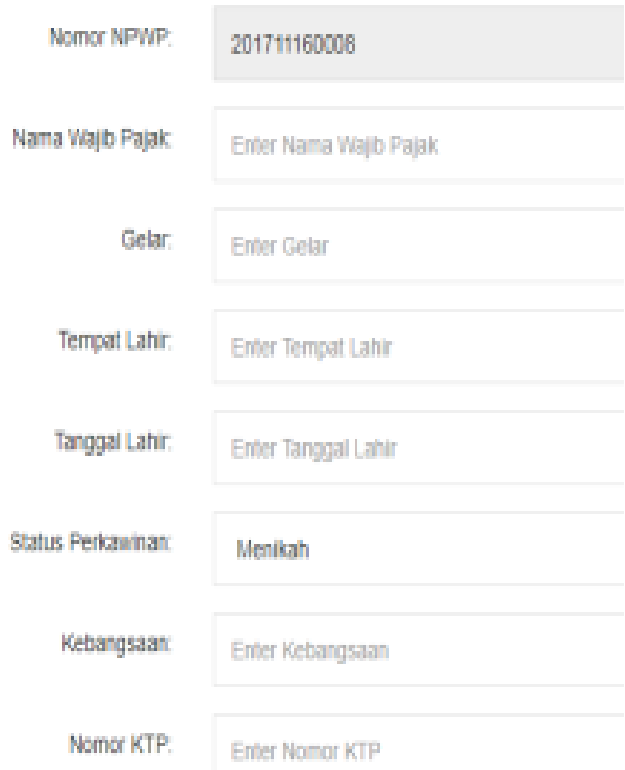

\section{Gambar 7 Pengisian Data Diri WP}

Tampilan Pengisian Data Tempat TinggalWP

Tampilan Pengisian Data Tempat TinggalWP berfungsi bagi Wajib Pajak untuk mengisi data tempat tinggal saat proses pendaftaran NPWP berlangsung. Data yang diinput adalah alamat, kelurahan, kecamatan, kota/kabupaten, kode pos, 102| Penerapan CR M dan provinsi. Tampilan Input Data Tempat Tinggal WP dapat dilihat pada Gambar 8.

\section{Slep 2 : Pengisian Data Tempat Tinggal}

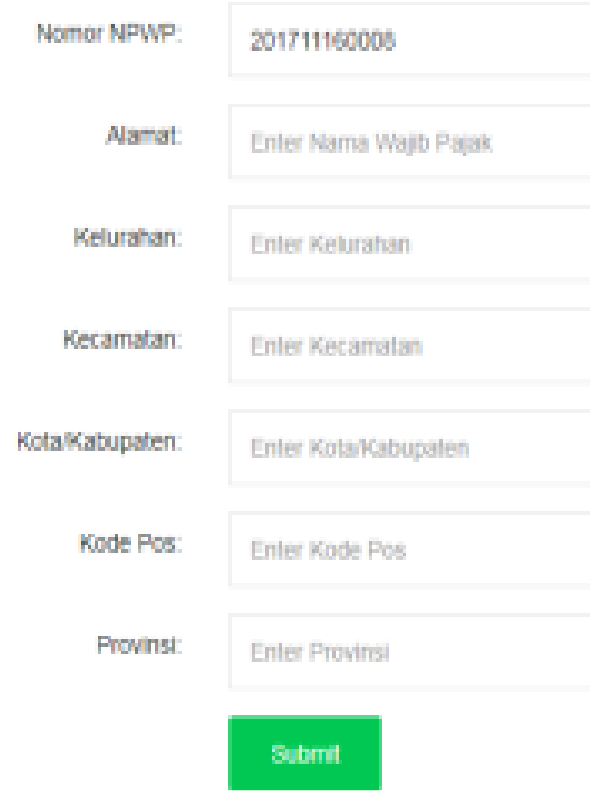

Gambar 8 Input Data Tempat Tinggal WP

\section{Tampilan Sumber Penghasilan WP}

Tampilan Sumber PenghasilanWP berfungsi bagi Wajib Pajak untuk mengisi data sumber penghasilan saat proses pendaftaran NPWP berlangsung. Data yang diinput adalah pekerjaan, kegiatan usaha, nama perusahaan, jabatan, dan pendapatan sebulan. Tampilan Sumber Penghasilan WP dapat dilihat pada Gambar 9.

\section{Step 3 : Sumber Penghasilan}

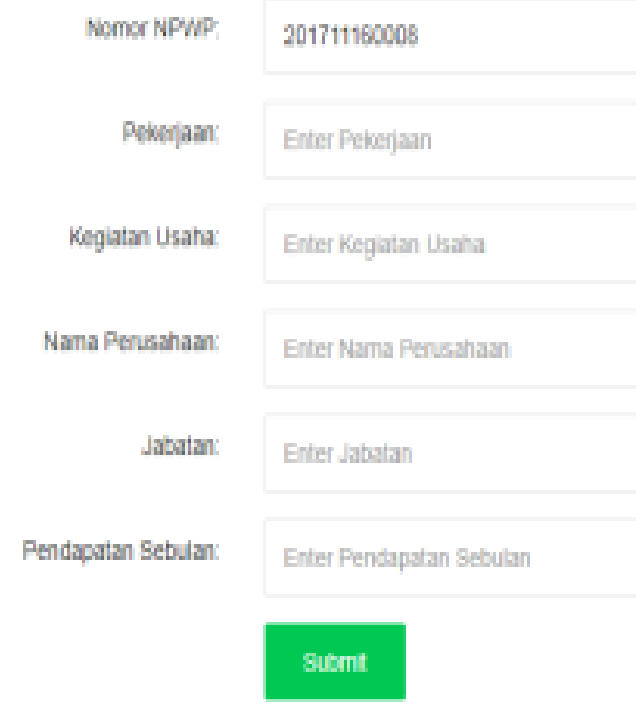

Gambar 9 Sumber Penghasilan WP 


\section{Rancangan Pengolahan Data User}

Tampilan pengolahan data user berfungsi bagi admin untuk menampilkan data user yang sudah diinput di form user. Data yang ditampilkan adalah nama, username, password, level, dan opsi untuk menghapus atau mengedit data user. Tampilan Pengolahan Data User dapat dilihat pada Gambar 10.

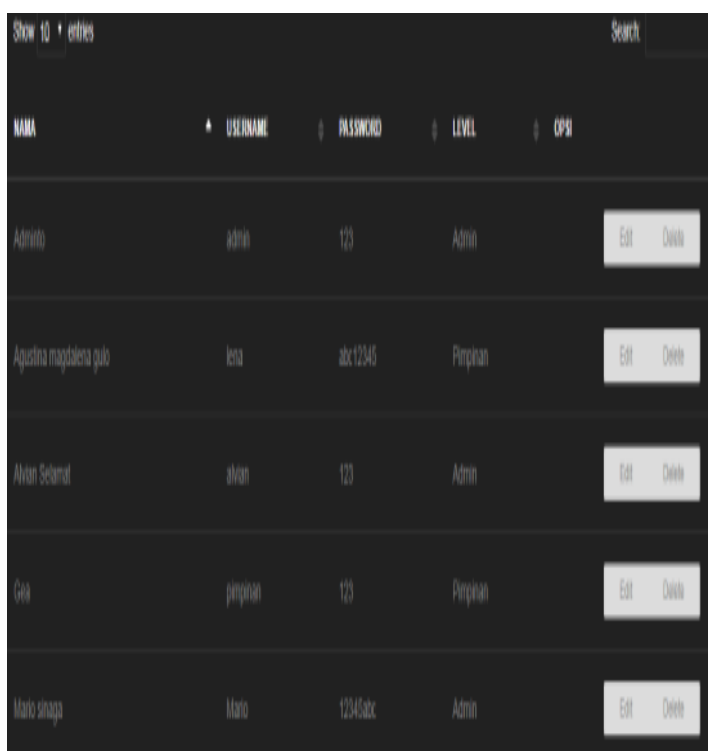

Gambar 10 Pengolahan Data User

\section{Tampilan Output Data Rekening}

Tampilan Pengolahan Data Rekening berfungsi bagi admin untuk menampilkan data rekening yang sudah diinput di form rekening. Data yang ditampilkan adalah nomor rekening dan opsi untuk menghapus atau mengedit data rekening. Tampilan Output Pengolahan Data Rekening dapat dilihat pada Gambar 11.

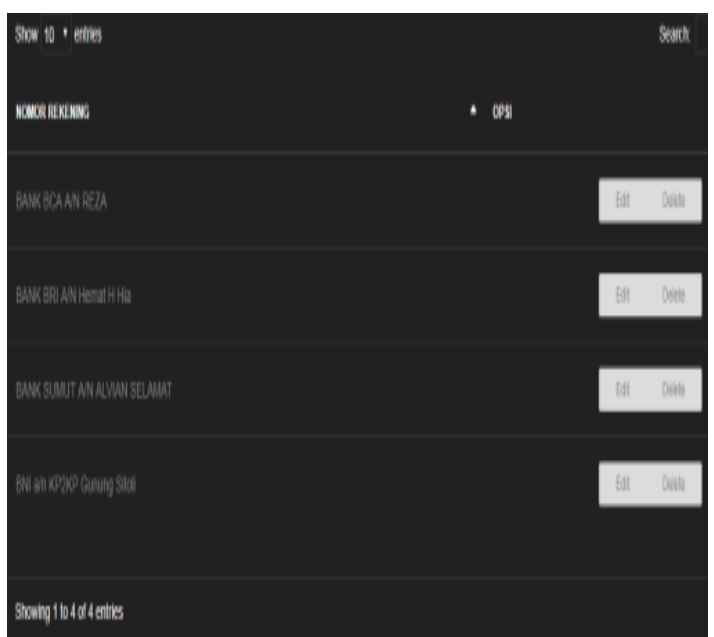

Gambar 11 Output Data Rekening

\section{Tampilan Output Data Peserta WP}

Tampilan Output Data Peserta WP berfungsi bagi admin untuk menampilkan data Peserta WP yang sudah diinput pada form pendaftaran WP. Data yang ditampilkan adalah NPWP, nama wajib pajak, kebangsaan, nomor HP, alamat, dan status pernikahan. Tampilan Output Data Peserta WP dapat dilihat pada Gambar 12.

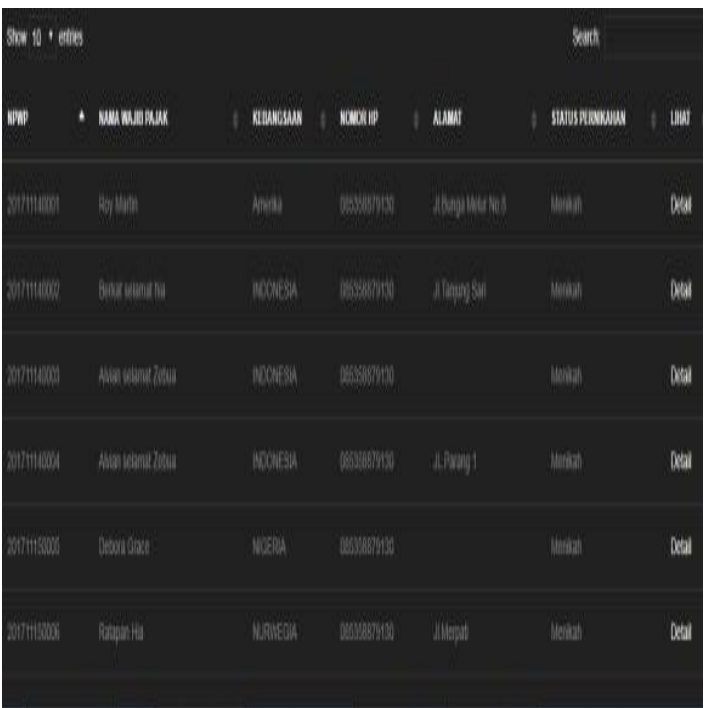

Gambar 12 Output Data Peserta WP

\section{Tampilan Output Pembayaran Pajak}

Tampilan Output Pembayaran Pajak berfungsi bagi admin untuk menampilkan Output Pembayaran Pajak yang sudah diinput di form pembayaran setoran pajak oleh wajib pajak. data yang ditampilkan adalah NPWP, nama wajib pajak, jumlah, ke rekening, tanggal pembayaran, dan tahun. Tampilan Output Pembayaran Pajak dapat dilihat pada Gambar 13.

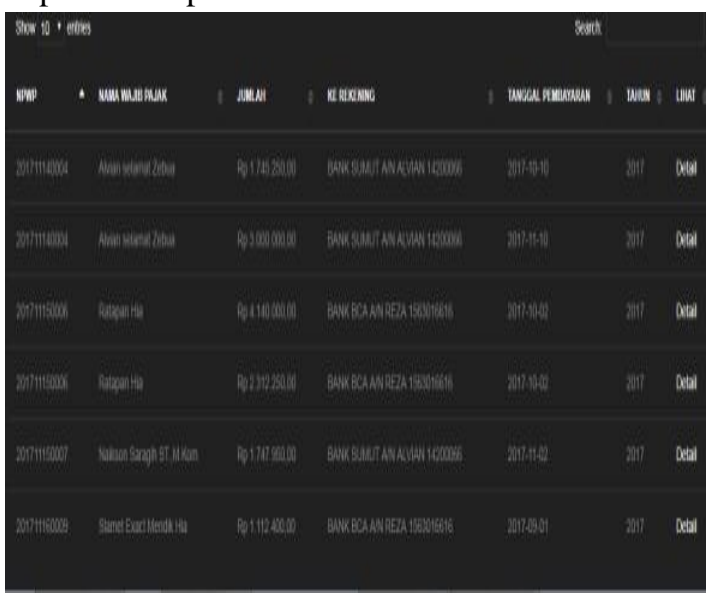

Gambar 13 Output Pembayaran Pajak 


\section{Tampilan Data Perhitungan Setoran Pajak}

Tampilan Data Perhitungan Setoran Pajak berfungsi bagi Wajib Pajak menginput data Setoran pajak pada tahun tertentu yang baru. Data yang diinput adalah gaji, tunjangan, jaminan kecelakaan kerja, jaminan kematian, iuran pensiun,dan iuran jaminan hari tua. Tampilan Data Perhitungan Setoran Pajak dapat dilihat pada Gambar 14.

\section{Seloran Pajak Untuk Tahun 2017}

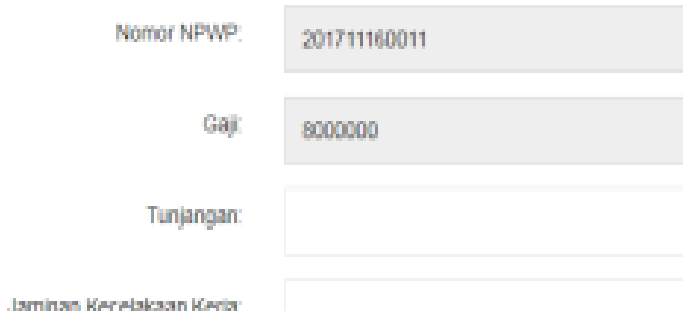

Jaminan Keceiakaan Kera

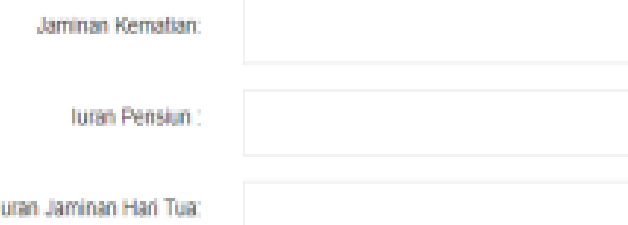

\section{Sutrin}

\section{Gambar 14 Data Perhitungan Setoran Pajak}

\section{Tampilan Pembayaran Pajak}

Tampilan ini digunakan untuk melakukan proses pembayaran untuk setoran pajak yang sudah dihitung sebelumnya. Data yang diinput adalah tanggal pembayaran, jumlah setoran pajak yang harus dibayar, rekening yang dituju dan gambar bukti pengiriman. Tampilan Pembayaran Pajak dapat dilihat pada Gambar 15.

\section{Pembayaran Pajak}

\section{Tanggal Pembsyaran \\ Jumbah Pagak Yang Hans \\ Dbayar \\ Rekening Yang Dtụu}

1960000

BNI AN KF2KP Gunungstoll 020

Gambar Ouk Pengiman

\section{Rombayarat}

\section{Tampilan Input Data Konsultasi}

Tampilan ini digunakan untuk melakukan proses input data konsultasi. Data yang diinput adalah hal dan isi konsultasi. Tampilan Input Data Konsultasi dapat dilihat pada Gambar 16.

\section{Menginput Data Konsultasi Baru}

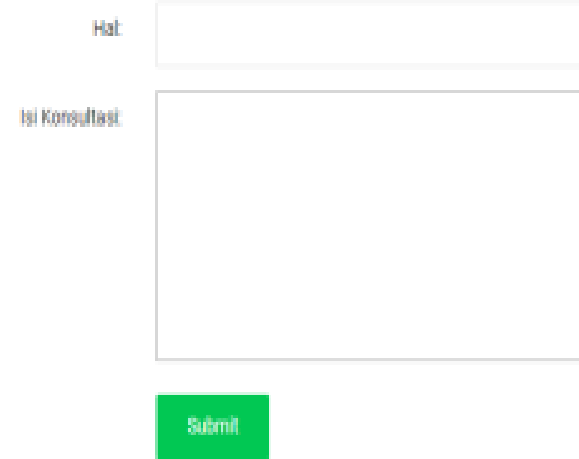

\section{Gambar 16 Input Data Konsultasi}

\section{Tampilan SMS Notifikasi Pendaftaran WP}

Tampilan ini digunakan saat sistem mengirim konfirimasi bahwa pendaftaran WP berhasil dilakukan dan notifikasi dikirim lewat media SMS. Tampilan Notifikasi Pendaftaran WP dapat dilihat pada Gambar 17.

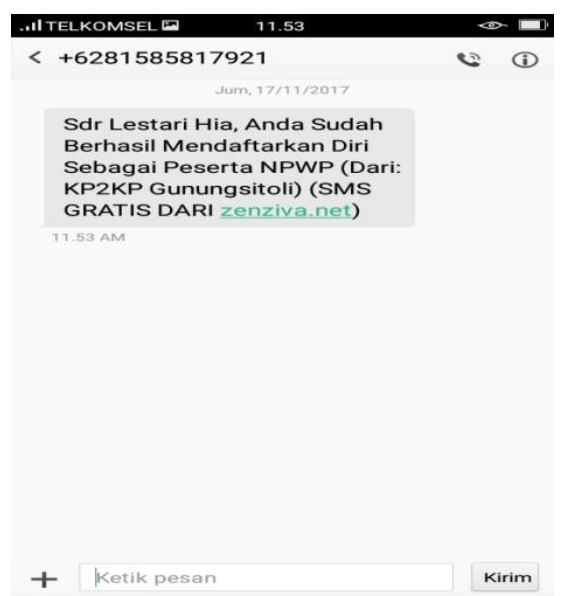

\section{Gambar 17 SMS Notifikasi Pendaftaran WP}

\section{Tampilan SMS Notifikasi Pembayaran Pajak}

Tampilan ini digunakan saat sistem mengirim konfirmasi bahwa notifikasi pembayaran pajak oleh Wajib Pajakdikirim lewat media SMS. Tampilan SMS Notifikasi Pembayaran Pajak dapat dilihat pada Gambar 18.

\section{Gambar 15 Pembayaran Pajak}




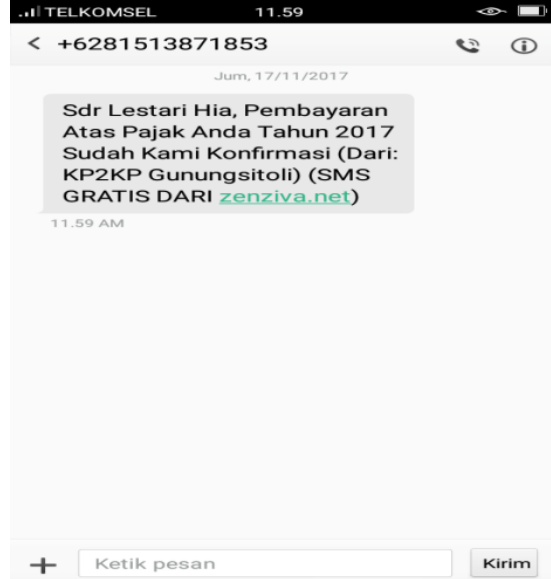

Gambar 18 SMS Notifikasi Pembayaran Pajak

Tampilan SMS Reminder Pembayaran Pajak

Tampilan ini digunakan saat sistem mengirim notifikasi pengingat (reminder) pembayaran pajak oleh WP sebelum jatuh tempo yang dikirim lewat media SMS. Tampilan Notifikasi Reminder Pembayaran Pajak dapat dilihat pada Gambar 19.

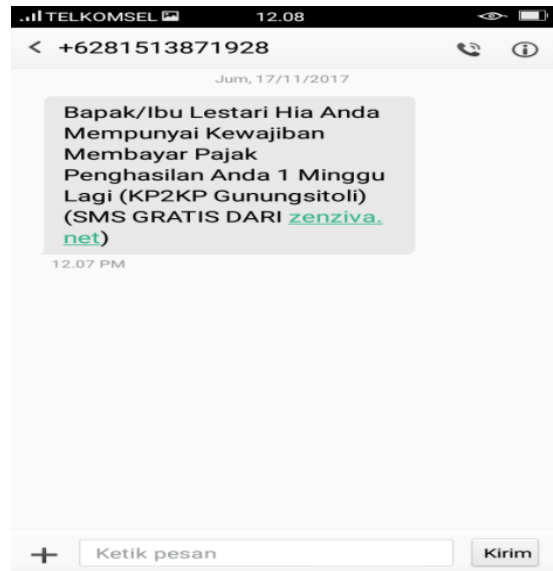

Gambar 19 SMS Reminder Pembayaran Pajak

\section{Tampilan Email Notifikasi Pendaftaran WP}

Tampilan ini digunakan saat sistem mengirim notifikasi bahwa pendaftaran NPWP berhasil dilakukan dan dikirim lewat media Email. Tampilan Email Notifikasi Pendaftaran NPWP dapat dilihat pada Gambar 20. hemathia33@gmail.com

ke saya

11.01 Tampilkan detailnya

Sdr Samuel Andri hia, Anda Sudah Berhasil Mendaftarkan Diri Sebagai Peserta NPWP (Dari: KP2KP Gunungsitoli)

This email is free from viruses and malware because avast! Antivirus protection is active. avast!

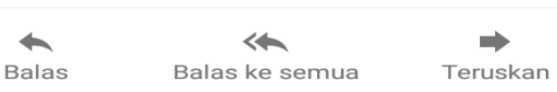

Gambar 20 Email Notifikasi Pendaftaran WP

Tampilan Email Notifikasi Pembayaran Pajak

Tampilan ini digunakan saat sistem mengirim notifikasi bahwa pembayaran pajak oleh Wajib Pajak dan dikirim lewat media Email. Tampilan Email Notifikasi pembayaran pajak dapat dilihat pada Gambar 21.

$$
\begin{aligned}
& \text { hemathia33@gmail.com } \\
& \text { ke saya }
\end{aligned}
$$$$
\text { 11.17 Tampilkan detailnya }
$$

Tampilkan kutipan teks

hemathia33@gmail.com

ke saya

11.21 Tampilkan detailnya

Sdr Samuel Andri hia, Pembayaran Atas Pajak Anda Tahun 2017 Sudah Kami Konfirmasi (Dari: KP2KP Gunungsitoli)

Tampilkan kutipan teks

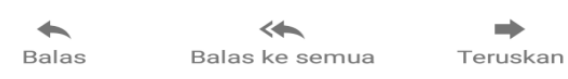

\section{Gambar 21 Email Notifikasi Pembayaran \\ Pajak}

\section{Tampilan Laporan Pendaftaran WP}

Tampilan Laporan Pendaftaran WP berfungsi bagi pimpinan untuk melihat Pendaftaran WP berdasarkan periode tertentu. Tampilan LaporanPendaftaran WP dapat dilihat pada Gambar 22 


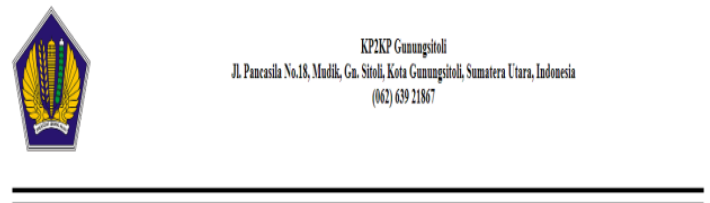

LAPORAY PENDAFTARAINPIIP 2017-11-11 s s 2017-11.30

\begin{tabular}{|c|c|c|c|c|c|}
\hline wo & 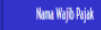 & Vempena & 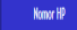 & Hant & 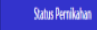 \\
\hline mantinaman & Nibustinght & 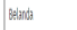 & 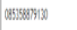 & Laring Gitung & Besmingeich \\
\hline 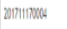 & Bincian & ghand & 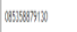 & 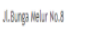 & stenveliat \\
\hline momizuse & ralusinght & М'ESH & mestem & LAseg netarkes & Minial \\
\hline mathers & Festid hia & мовен & arsssystix & 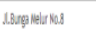 & Manmelith \\
\hline 20 & Latalitia & Nrongag & arstsesilo & 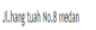 & Minial \\
\hline moninawa & Rasipaxtis & Norngaja & arswasilo & 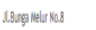 & 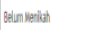 \\
\hline monimaxe & Sisul hutitili & Мовен & arstersing & Lingungsit & Meidath \\
\hline
\end{tabular}

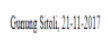

Distujiolith:

Gambar 22 Laporan Pendaftaran WP

Tampilan Laporan Pembayaran Pajak

Tampilan laporan Pembayaran Pajak berfungsi bagi pimpinan untuk melihat Pembayaran Pajak berdasarkan periode tertentu. Tampilan Laporan Pembayaran Pajak dapat dilihat pada Gambar 23.

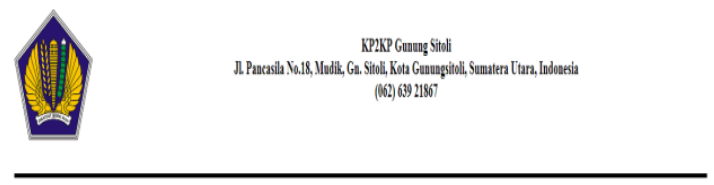

LAPORIV PEIBIYARAI PAJAK DARR 2017-10.01 SD 2017-11.130

\begin{tabular}{|c|c|c|c|c|c|}
\hline map & Mand With hijh & Jumb & Eletaring & 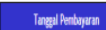 & ith \\
\hline 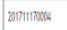 & sinatian & 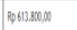 & aus & 20171.10101 & 201 \\
\hline 29m & Festat hia & 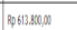 & 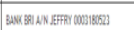 & $2007 \cdot 1+1001$ & 2017 \\
\hline 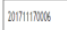 & Letritha & 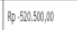 & 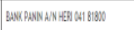 & 2017:001 & 2017 \\
\hline montraxo & Rexinarabo & 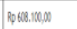 & 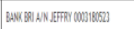 & 2077 : 102 & 207 \\
\hline momaxus & 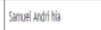 & Rop 131210,0 & 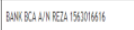 & 201:AMs & $2 n$ \\
\hline martinuses & Nabus tragh & 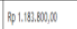 & 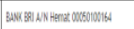 & 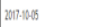 & 2017 \\
\hline 20 & Nabus srigh & 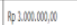 & 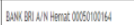 & 2001.005 & 2017 \\
\hline
\end{tabular}

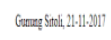

Disetyin Olth

Gambar 23 Laporan Pembayaran Pajak

\section{KESIMPULAN}

Dari hasil penelitan ini, dapat diambil kesimpulan bahwa telah dihasilkan suatu Sistem Informasi Kantor Pelayanan Penyuluhan Dan Konsultasi Perpajakan (KP2KP) Kota Gunungsitoli dengan Pendekatan CRM (Customer Relationship Management) yang telah dirancang dan dibangun dengan memasukkan aspek loyalitas, kepuasan Wajib Pajak, memiliki tujuan meningkatkan Pendapatan Negara, dan meningkatkan keunggulan bersaing dibanding dengan Sistem yang konvensional. Sistem Informasi ini dapat memaksimalkan kegiatan publikasi, memudahkan dalam penyuluhan dan konsultasi di antara Petugas Pajak dan Wajib Pajak sehingga akan mendorong WP yang telah ada dan Calon Wajib Pajak untuk membayar Pajak dengan sebenar-benarnya.

\section{DAFTAR PUSTAKA}

[1] Al Fatta, Hanif, "Analisis dan Perancangan Sistem Informasi", Yogyakarta, Andi, 2007

[2] Anhar, "PHP \& MySQL Secara Otodidak", Jakarta, PT. TransMedia, 2010

[3] Buttle, Francis, \& Maklan, Stan, "Customer Relationship Management: Concepts and Technologies", $3^{\text {rd }}$ Editon, New York, Elsevier, 2015

[4] Hidayat, "Cara Cepat Membangun Website dari Nol", Yogyakarta, Andi, 2010

[5] Irianto, Edi Slamet, "Pengantar Ilmu Pajak: Kebijakan Dan Implementasi" Jakarta, Raja Grafindo Persada, 2012

[6] Lerdorf, Rasmus, "Programming PHP", London: O’Reilly Media, 2006

[7] Muslihudin, Muhamad, \& Oktafianto, "Analisis dan Perancangan sistem Informasi Menggunakan Model Terstruktur dan UML", Yogyakarta, Andi, 2016

[8] Oneto, Erima \& S, Yosep, "Anti Gaptek Internet”, Jakarta, PT Kawan Pustaka, 2009

[9] Undang - Undang Republik Indonesia Nomor 16 Tahun 2009

[10] C. Mugunthan, G.Kalaiarasi, "Theoretical Framework of Customer Relationship Management: An Overview", dalam International Journal of Scientific Research and Management (IJSRM), vol. 5 no, 7, 2015, dalam www.ijsrm.in/v5i7/78\%20ijsrm.pdf, diakses tanggal 14 Juli 2018

[11] OECD, "Improving Taxpayer Service Delevery Channel", 2007 dalam https://www.oecd.org/tax/ administration/38528306.pdf, diunduh tanggal 14 Juli 2018 